\title{
Analysis of Online Learning by Using Usability Testing During the Covid-19 Pandemic
}

\author{
Hendrik Setyo Utomo ${ }^{1 *}$, Veri Julianto ${ }^{2}$, Ahmad Rusadi Arrahimi ${ }^{3}$ \\ ${ }^{1}$ Politeknik Negeri Tanah Laut \\ ${ }^{2}$ Politeknik Negeri Tanah Laut \\ ${ }^{3}$ Politeknik Negeri Tanah Laut \\ *Corresponding author. Email: hendrik.tomo@politala.ac.id
}

\begin{abstract}
Online learning is defined as learning that takes place without direct or face-to-face interaction between lecturers and students, but rather through the use of the internet. Even if students are at home, lecturers ensure that teaching and learning activities can take place. The solution, lecturers can design learning media as innovations by utilizing online media (online). Some online media providing online communication such as WhatsApp (WA) and Google Drive does not work as Learning Management System (LMS). Those two communication media example not yet centralized in one place in the cloud. Lecturers has problems in communicating material changes to team teaching so they are not flexible in changing materials. The solution is to build a centralized learning media design using cloud based software called Mediawiki. The Usefulness Criterion has a value of 85.02 (Strongly Agree), the Ease of Use Criteria (Ease of Use) has a value of 82.18 (Strongly Agree), the Ease of Learning criterion has a value of 82.89 (Strongly Agree), and the Satisfaction Criteria has a value of 81.32 (Strongly Agree) (Strongly Agree).
\end{abstract}

Keywords: Online Learning, Covid-19 Pandemic, Usability Testing, Mediawiki.

\section{INTRODUCTION}

\subsection{Background}

Online learning is defined as learning that takes place through the internet rather than face to face between teachers and students. Even while students are at home, lecturers guarantee that teaching and learning activities continue. Lecturers can create innovative learning media by leveraging online media as a solution (online)

Lecturers of The Information Technology Study Program teaching materials used in the form of documents (.ppt, .doc and .pdf) or by using video. Lecturers provide material files or teaching materials before the pandemic until now (pandemic) to students via Whatsapp (WA) and Google Drive links, not yet centralized in one place in the cloud. As well as lecturers in communicating material changes, team teaching lecturers have difficulty, so they are not flexible in changing materials.

Based on these problems, the solution is to build a centralized learning media design using cloud software. Lecturers of courses and team teaching lecturers can enter, make changes and delete centralized materials. Uploaded material files can be in the form of documents or videos. Lecturers do not need to return material files to students via Whatsapp (WA) and Google Drive links. Students can actively surf independently with a system that has been built in the cloud. The research results to be achieved are building a system in the cloud, conducting socialization to lecturers and students and analyzing the user experience of the system that has been built.

\subsection{Problem Formulation}

The research problem is:

1. How to examine the necessity for user experience analysis in the collaboration of the course teaching team, based on the context that has been presented.

2. How to build a software system in the cloud in the collaboration of the course teaching team?

3. How to socialize the software system to lecturers and students?

4. How to analyze the user experience in the collaboration of the course teaching team? 


\subsection{Research Objectives}

The objectives to be achieved in this research are as follows.

1. Analyzing the need for user experience analysis in the collaboration of the course teaching team.

2. Build a software system in the cloud on the collaboration of the course tutor team.

3. Socializing the software system to lecturers and students.

4. Analyzing the user experience in the collaboration of the course tutor team.

\section{LITERATURE REVIEW}

Previous research that can be used as a reference can be seen from Table 1:

\subsection{Usability Test}

Bauer (2010) defines usability testing as follows, " Usability testing has typically been used to assess efficiency, learning ease, and the capacity to understand how to complete interactive tasks without trouble or errors." On the other hand, is used to assess efficiency, learning ease, and the capacity to learn how to interact without difficulty or error.

\subsection{Media Wiki}

The GNU General Public License regulates MediaWiki, a wiki software package. MediaWiki is software that was designed primarily for Wikipedia and other Wikimedia Foundation projects, but it is now widely used. MediaWiki is written in PHP with texvc and utilizes the MySQL relational database management system to render mathematical symbols.

Table 1. Previous research related to usability test

\begin{tabular}{|c|c|c|}
\hline No & Researcher (year) & Research result \\
\hline 1 & Adinegoro (2018) & $\begin{array}{l}\text { In this study, two testing methods were used: first, objective testing using } \\
\text { direct testing of respondents in using the website using scenario tasks with } \\
\text { the parameters of task success rate, time per completed task, number of } \\
\text { clicks during task completion, and error during task performance, which was } \\
\text { given to } 10 \text { respondents; and second, the UEQ Questionnaire, which has six } \\
\text { scales. } 20 \text { respondents were given the following criteria: attractiveness, } \\
\text { efficiency, perspicuity, dependability, stimulation, and uniqueness. } \\
\text { Respondents range in age from } 16 \text { to } 65 \text { years old and have never used any } \\
\text { of the three websites examined. Second, for more in-depth user perceptions } \\
\text { and difficulties, subjective testing employing focus group talks is used. The } \\
\text { results of the two tests show that the Blibli.com website is superior to } \\
\text { Lazada.co.id and JD.id. }\end{array}$ \\
\hline 2 & Yulianti (2017) & $\begin{array}{l}\text { In this study, usability was improved with the goal of boosting the usability } \\
\text { value by creating a recommended design. The WEBUSE questionnaire was } \\
\text { used to assess the usability of the proposed FP website design, and the } \\
\text { results reveal that the average usability value has increased overall. This } \\
\text { implies that the proposed design is superior to the current design in terms of } \\
\text { functionality and ease of use. The website went from a moderate (value } 0.4- \\
0.6 \text { ) to a good (value } 0.4-0.6 \text { ) rating (value } 0.4-0.8 \text { ). Usability improved by } \\
0.07 \text { points in the content, organization, and readability categories, } 0.15 \\
\text { points in navigation and links, } 0.11 \text { points in user interface design, and } 0.14 \\
\text { points in performance and effectiveness. }\end{array}$ \\
\hline 3 & Yuditha Ichsani (2017) & $\begin{array}{l}\text { The results of a usability examination of the websites of Indonesian State } \\
\text { Universities (PTNs) that received Accreditation A from the National } \\
\text { Accreditation Board for Higher Education (BAN-PT) in } 2013 \text { and are still valid } \\
\text { till 2017. Gajah Mada University has the greatest user satisfaction score in } \\
\text { terms of websites. Diponegoro University is the university with the lowest } \\
\text { user satisfaction rating. The average QUIS findings and the average degree } \\
\text { of usability problems have a high, actual, and unidirectional association ( } r= \\
0.21, p=0.000) \text {, according to the results of the correlation test. }\end{array}$ \\
\hline
\end{tabular}

The logo represents how the markup language joins articles with double brackets ("[[","]]"). Other software, such as memcached, a squid cache system, and TeX, a math renderer, can help MediaWiki increase its efficiency and functionality. Users can add features they've made for usage on MediaWiki by using extensions and hook systems.

\subsection{System Usability Scale (SUS)}

Scale of System Usability is one of the user testing methods (usability) that provides a fast and reliable measuring tool (Brooke, 1996). To measure user satisfaction, you can use the System Usability Scale (SUS) which is a simple scale, in which there are 10 statement items that provide a global view of usability 
subjectivity assessment. Five response alternatives will be provided for each of the ten statement items, ranging from agree to strongly disagree.

\section{RESEARCH METHODS}

The following stages compose the research methodology adopted for this research.

1. Conducting needs analysis in user experience analysis in the collaboration of the course tutor team at the Tanah Laut State Polytechnic.

2. Collecting data from courses and a team of course lecturers at the Tanah Laut State Polytechnic in 2021.

3. After obtaining the data, it is followed by the creation of a web for collaborative material creation for each course, as well as modules and training to ensure that each respondent lecturer practices collaborative lecture material creation on the web wiki created. In this process, the web is also optimized to get a new hosting server in order to increase its service capacity.

4. Next is the process of filling and using it by lecturers at the Tanah Laut State Polytechnic. At this stage, assistance is also carried out so that problems that occur can be assisted in solving them.

5. The next stage is distributing questionnaires to the contributing lecturers. Technically, this questionnaire will be distributed using various possible ways, for instance, in electronic or physical form. The results of the questionnaire are then derecapitulated and, if necessary, a system usage log file will also be included as material to be studied at a later stage.

6. Furthermore, the recapitulated data is processed using the planned analysis method so as to provide research conclusions. These results will provide direction for the next system development in terms of negative and positive aspects of user input on system development.

7. The final stage is to make reports and make articles for publication according to the plan.

\section{RESULTS AND DISCUSSION}

The research begins with the implementation of the system in the form of a web with the Wiki Source platform. The following is an illustration of student interaction with lecturers in sharing lecture resources before the existence of a web wiki shown in Figure 1.

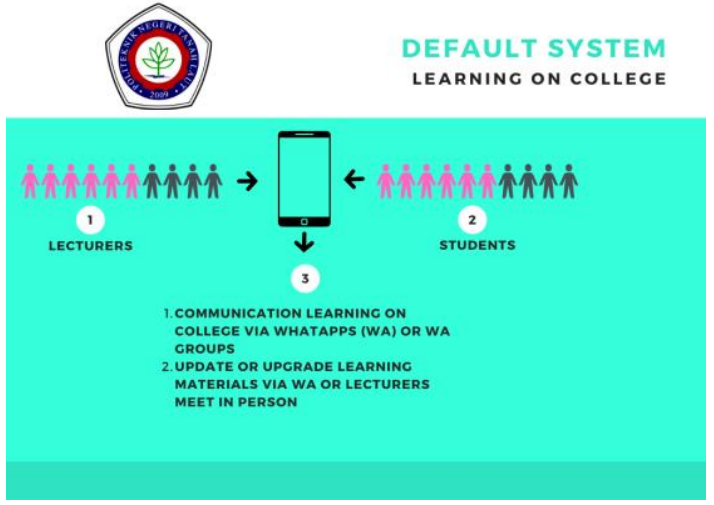

Figure 1. Running system before using wikisource

The following is an illustration of the system that was built that replaces the conventional way of sharing lecture resources between lecturers and students to using a cloud-based wiki shown in Figure 2.

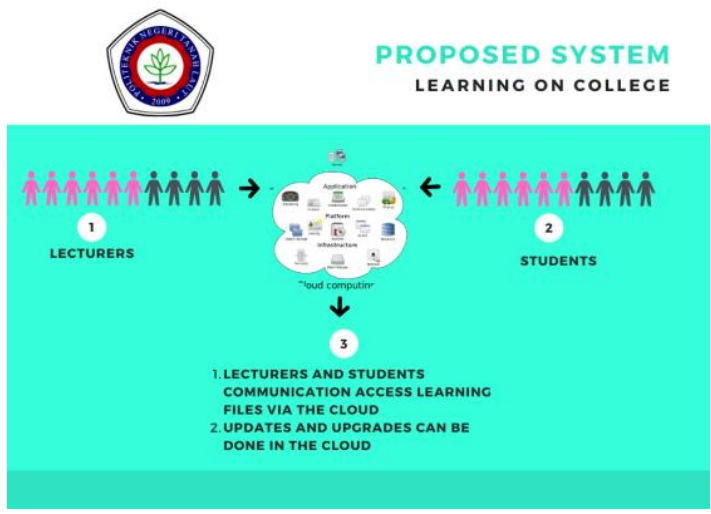

Figure 2. Running system using wikisource

The following Figure 3 is the software that has been built and placed on the hosting address at wikisource.politala.ac.id. After the web is installed on the host, the initial users, lecturers and students, conduct a trial run before completing the prepared questionnaire.

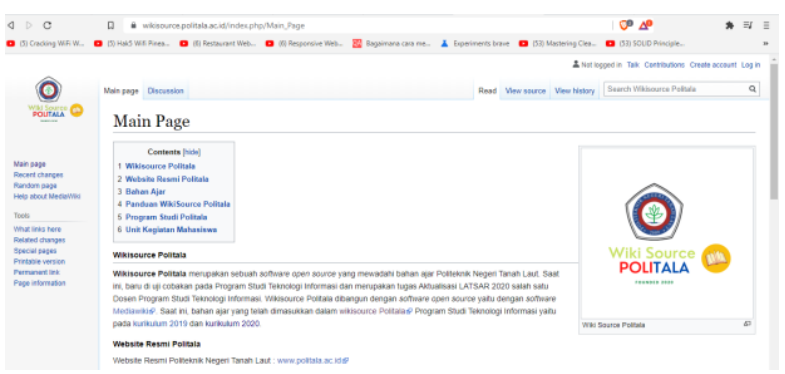

Figure 3. Software that resides in the cloud hosting

The WikiSource Politala questionnaire was distributed to 54 lecturers and students, consisting of 14 lecturers and 44 students. This questionnaire uses the Google Form application which is informed through the Google Meet chat. The following criteria and assessment index: 


$\begin{array}{ll}0 \%-19.99 \% & : \text { Index of Strong Disagreement } \\ 20 \%-39.99 \% & : \text { Index of Disagreement } \\ 40 \%-59.99 \% & : \text { Index of Complete Agreement } \\ 60 \%-79.99 \% & : \text { Index of agreement between } \\ 80 \%-100 \% & : \text { Agree Wholeheartedly }\end{array}$

The survey results are shown in Figures 4 to 7 below:

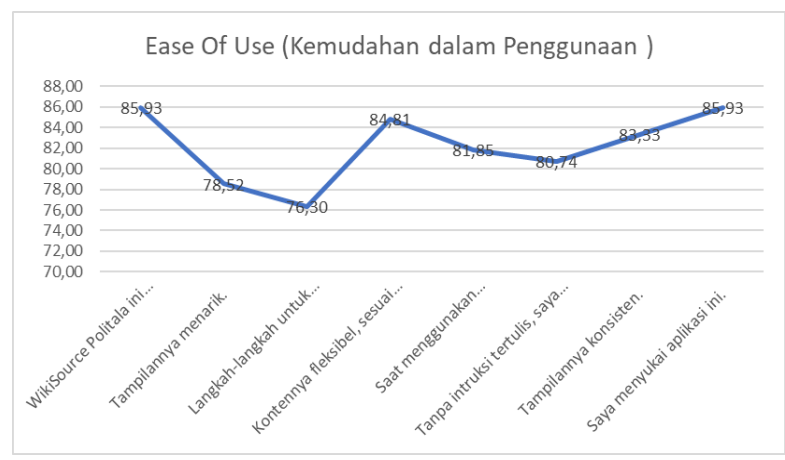

Figure 4. Ease Of Use Questionnaire Graph

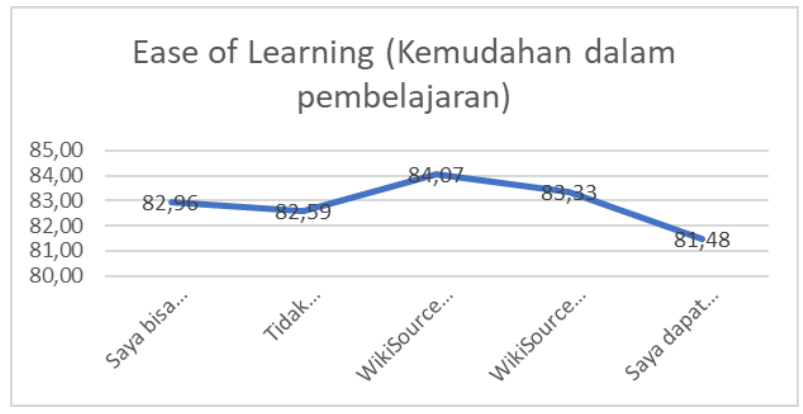

Figure 5. Ease Of Learning Questionnaire Graph

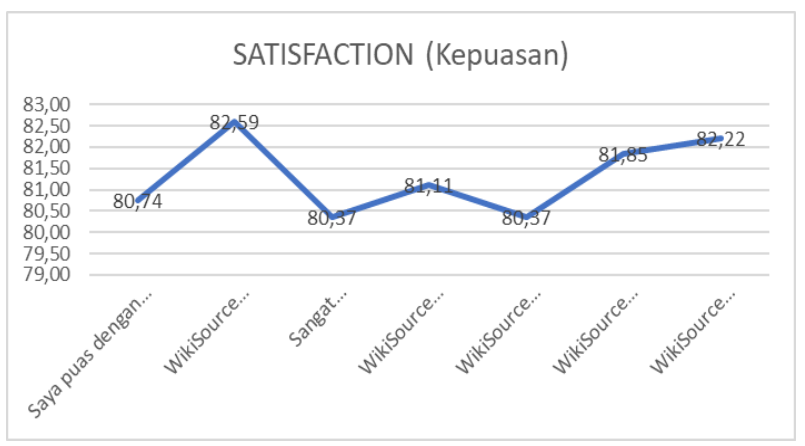

Figure 6. Satisfaction Questionnaire Graph

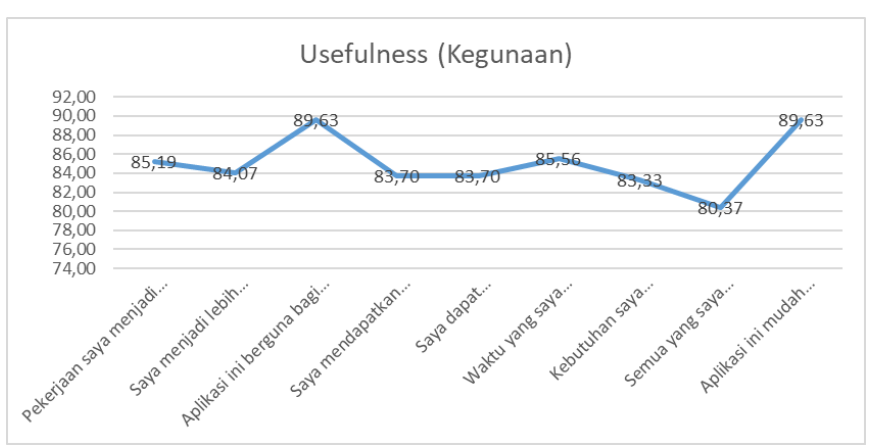

Figure 7. Graph of the Usefulness Questionnaire

\section{CONCLUSION}

The conclusion of this research is based on the results of the questionnaire, which indicate that the Usefulness Criteria is 85.02 (Strongly Agree), the Ease of Use Criteria is 82.18 (Strongly Agree), the Ease of Learning Criteria is 82.89 (Strongly Agree), and the Satisfaction Criteria is 81.32 (Strongly Agree) (Strongly Agree)

\section{AUTHORS' CONTRIBUTIONS}

Hendrik Setyo Utomo conceptualized the project, developed the primary conceptual ideas, and outlined the proof. Ahmad Rusadi A. worked out the technical details of the proposed experiment, performed the numerical calculations, and wrote the manuscript. Veri Julianto and Hendrik Setyo Utomo proposed the questions for survey experiment in discussions with Ahmad Rusadi A.

\section{ACKNOWLEDGMENTS}

First of all, we would like to express our gratitude to Allah SWT because it is due to His abundance of grace that this research can be completed. Thanks also to the leadership of the Tanah Laut State Polytechnic, especially the director, Dr. Mufrida Zein who has provided support as well as among lecturers and students who volunteered to fill out surveys and try out the system that had been developed.

\section{REFERENCES}

[1] Adinegoro, A. L. T., Rokhmawati, R. I., \& AzZahra, H. M (2018), Analisis Pengalaman Pengguna pada Website E-commerce Dengan Menggunakan Usability Testing dan User Experience Questionnaire (UEQ)(Studi pada Lazada. co. id, Blibli. com dan JD. id), Jurnal Pengembangan Teknologi Informasi dan Ilmu Komputer, Vol 2 No 11.

[2] Bauer, D. T., Guerlain, S., \& Brown, P. J., (2010), The Design and Evaluation of Graphical Display for Laboratory Data. 
[3] Barrows, H.S. (2000). Problem based learning applied to medical education. Springfield IL: Southern Illinois University Press.

[4] Brooke, (1986). SUS a quick and dirty usability scale. Usability evaluation in industry, 189(194), 47.

[5] https://www.mediawiki.org/wiki/MediaWiki (Disunting terakhir pada 26 Mei 2021, pukul 13:38).

[6] Ichsani, Y. (2017), Evaluasi Performa Usability Situs-Situs Web Perguruan Tinggi Negeri Di Indonesia Yang Terakreditasi "A" Tahun 2013 Sertaperbandingan Kondisi Situs Web Tahun 2014 Dan 2017, JURNAL TEKNIK INFORMATIKA VOL.10 NO.2.

[7] Sukamto, R. A., \& Shalahuddin, M. (2018). Rekayasa Perangkat Lunak Terstruktur. In Informatika.

[8] Yulianti, M., Aknuranda, I. \& Wardani, N. H. (2017), Evaluasi Usability dan Perbaikan Desain Antarmuka Pengguna Situs Web Fakultas Pertanian (FP) Universitas Brawijaya, Jurnal Pengembangan Teknologi Informasi dan Ilmu Komputer, Vol 1 No 11. 